\title{
KESALAHAN KONSTRUKSI KONSEP MAHASISWA PADA MATERI HIMPUNAN DAN DEFRAGMENTASI STRUKTUR BERPIKIRNYA
}

\author{
Latifah Mustofa Lestyanto ${ }^{1}$, Syaiful Hamzah Nasution ${ }^{2}$, \\ Ety Tejo Dwi Cahyowati ${ }^{3}$, M. Shohibul Kahfi ${ }^{4}$ \\ 1,2,3,4 Universitas Negeri Malang \\ Corresponding Author: 1atifah.mustofa.fmipa@um.ac.id"
}

\begin{abstract}
This research was conducted to identify errors in the construction of concepts and to know the form of defragmentation of students' thinking structures on set material. Data collection was done by asking students to answer on the main test questions. Data were analyzed by data reduction, data presentation, and conclusion. The results of the research indicate that the errors in the construction of mathematical concepts of students on set material were: 1) pseudo-constructions in the form of true pseudo and false pseudo, 2) misconstruction, 3) misconnection, and 4) logical thinking errors. The forms of defragmentation or the process of rearranging the thinking structures of students who experience concept construction errors in the set were conducted by giving scaffolding and cognitive conflict.
\end{abstract}

Keywords: Defragmentation; Misconstruction; Tbinking structure

How to cite: Lestyanto, L. M., Nasution, S. H., Cahyowati, E. T. D., \& Kahfi, M. S. (2019). Kesalahan Konstruksi Konsep Mahasiswa pada Materi Himpunan dan Defragmentasi Struktur Berpikirnya. JRPM (Jurnal Review Pembelajaran Matematika), 4(2), 128-142.

\section{PENDAHULUAN}

Salah satu capaian pembelajaran pada ranah pengetahuan yang harus dimiliki mahasiswa program studi Pendidikan Matematika di Universitas adalah menguasai konsep pedagogik dan didaktik matematika untuk melaksanakan pembelajaran di pendidikan menengah serta untuk studi lanjut. Kemampuan ini sangat diperlukan oleh seorang calon pengajar matematika yang akan menerapkan pengetahuan konsep matematika yang dimilikinya kepada para peserta didiknya di kemudian hari nanti. Kemampuan pemahaman konsep matematika peserta didik penting untuk dimiliki karena matematika merupakan ilmu pengetahuan yang menjadi dasar dari ilmu pengetahuan yang lain. Banyak sekali terapan ilmu matematika dalam kehidupan sehari-hari, beberapa diantaranya dalam bidang ekonomi, teknik, fisika dan statistika. Hal ini sesuai dengan pendapat Ganal dan Guiab (2014) yang menyatakan bahwa matematika merupakan alat utama untuk mengembangkan berpikir logis dan kemampuan kognitif tingkat tinggi peserta didik.

Pencapaian kemampuan kognitif peserta didik dipengaruhi oleh beberapa faktor, salah satunya adalah faktor eksternal yaitu dari guru pada saat proses pembelajaran. Kemampuan guru dalam bidang kognitif merupakan suatu hal yang wajib dimiliki oleh mahasiswa 
pendidikan matematika sebagai calon guru dan didukung dengan kemampuan dalam mengelola pembelajaran di dalam kelas. Namun pada kenyataannya, masih banyak mahasiswa calon guru matematika yang kurang memahami konsep matematika itu sendiri. Hal ini terlihat dari kesalahan mereka pada saat menyelesaikan soal awal terkait dengan materi fungsi yang diberikan oleh peneliti. Kesalahan ini bahkan terjadi pada mahasiswa tingkat akhir. Salah satu kesalahan mahasiswa tersebut tampak pada Gambar 1 berikut.

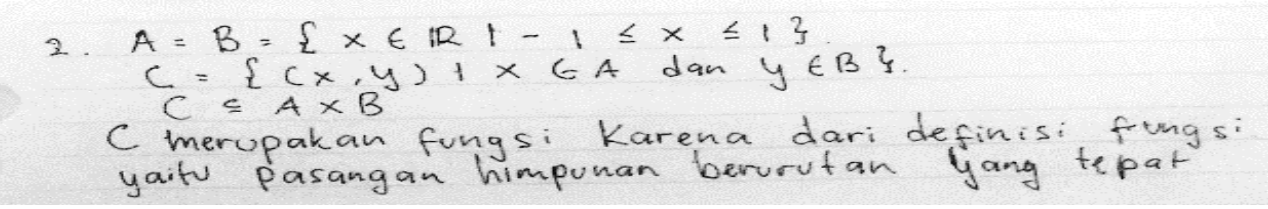

Gambar 1. Contoh kesalahan mahasiswa pada materi fungsi

Terjadinya kesalahan mahasiswa pada saat menyelesaikan soal sangat dimungkinkan karena terdapat kesalahan pada saat mengonstruksi konsep. Frederiksen, Mislevy, dan Bejar (dalam Almeda, Cruz, \& Dy; 2013) mengemukakan bahwa kesalahan pada saat mengkonstruksi konsep berakibat pada aplikasi dari pengetahuan itu sendiri. Lebih lanjut, kesalahan tersebut dapat mempengaruhi pemahaman konsep peserta didik. Menurut Subanji (2015), kesalahan peserta didik dalam mengkonstruksi konsep matematika diklasifikasikan dalam lima bentuk, yaitu: 1. pseudo-construction yaitu hasil konstruksi matematika peserta didik seringkali berbeda dengan apa yang dituliskan peserta didik, 2. misconstruction yaitu proses pembentukan konsep matematika tidak sempurna, dalam pembentukan konsep, ada bagian dari konsep yang tidak terkonstruksi, 3. misanalogical construction (kesalahan berpikir analogis) merupakan proses pembentukan konsep matematika melalui analogi, namun ada penyimpangan dalam penggunaan berpikir analogis, 4. misconnection proses pembentukan konsep matematika, dimana bagian-bagian konsep telah terkonstruksi namun belum ada koneksi antar bagian konsep, dan 5. mislogical construction disebut juga dengan kesalahan berpikir logis, yaitu proses pembentukan konsep matematika melalui berpikir logis, namun ada penyimpangan dalam penggunaan kaidah logika.

Untuk mengurangi terjadinya kesalahan mahasiswa pada saat mengonstruksi konsep, salah satunya dapat dilakukan defragmentasi struktur berpikir sesuai dengan jenis kesalahan yang dilakukan oleh mahasiswa. Subanji (2016) menyatakan bahwa defragmentasi struktur berpikir merupakan fenomena perubahan tatanan skema (struktur berpikir) dalam rangka memperbaiki fragmentasi struktur berpikir.

Melalui penelitian ini akan diidentifikasi kesalahan konstruksi konsep mahasiswa pada saat menyelesaikan soal materi himpunan serta bentuk defragmentasi struktur berpikir untuk 
mengatasinya. Materi himpunan dipilih untuk penelitian ini karena materi tersebut merupakan materi dasar bagi mahasiswa pendidikan matematika dan merupakan materi yang sudah pernah diperoleh di bangku sekolah menengah.

\section{METODE PENELITIAN}

Penelitian ini merupakan penelitian deskriptif kualitatif. Penelitian ini bertujuan untuk memaparkan kesalahan konstruksi konsep mahasiswa pendidikan matematika tingkat pertama, utamanya pada materi himpunan. Subjek penelitian adalah mahasiswa prodi Pendidikan Matematika Universitas Negeri Malang angkatan 2017 offering D, yang terdiri dari 3 mahasiswa. Ketiga mahasiswa tersebut masing-masing merupakan perwakilan dari kategori kemampuan kognitif tinggi, sedang dan rendah. Pengelompokkan kategori mahasiswa tersebut didasarkan pada hasil tes yang dilakukan sebelumnya dengan mengikuti kriteria Tabel 1. Dalam penelitian ini, peneliti membuat 4 butir soal pada soal tes utama dan 4 butir soal yang disertai beberapa alternatif jawaban pada soal tes pendukung.

Tabel 1. Kriteria Pengelompokan Kemampuan Kognitif Mahasiswa

\begin{tabular}{cc}
\hline Interval Hasil Tes $\left(\boldsymbol{x}_{\boldsymbol{i}}\right)$ & Kategori \\
\hline$x_{i} \geq 80$ & Tinggi \\
$45<x_{i}<80$ & Sedang \\
$x_{i} \leq 45$ & Rendah \\
\hline
\end{tabular}

Dalam proses pengumpulan data, langkah pertama yang dilakukan adalah meminta mahasiswa mengerjakan soal tes utama. Mahasiswa diminta untuk menentukan kebenaran setiap pernyataan sekaligus memberikan alasannya. Setelah itu, kegiatan dilanjutkan melakukan wawancara untuk melengkapi data tentang struktur berpikir mahasiswa dalam menyelesaikan soal-soal tersebut. Soal tes pendukung kemudian diberikan untuk meyakinkan bahwa yang dipikirkan mahasiswa benar-benar seperti apa yang dituliskan dengan apa yang diungkapkan.

Berdasarkan data yang telah diperoleh, selanjutnya peneliti menganalisis jenis-jenis kesalahan konstruksi konsep yang dilakukan mahasiswa. Agar mahasiswa memperoleh pemahaman yang utuh pada materi tersebut, selama proses wawancara peneliti melakukan defragmentasi pada mahasiswa sesuai dengan jenis kesalahan yang dilakukan mahasiswa tersebut. 


\section{HASIL DAN PEMBAHASAN}

\section{A. Subjek M1}

Adapun Hasil jawaban M1 pada soal tes utama diperoleh hasil pada Gambar 2 berikut ini.

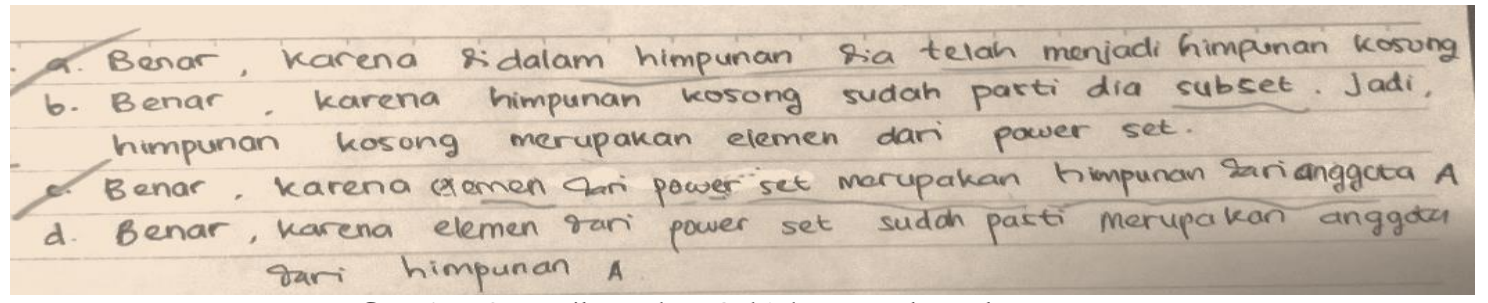

Gambar 2. Hasil Jawaban Subjek M1 pada soal tes utama

Berdasarkan Gambar 2 sekilas dapat dilihat bahwa subjek M1 melakukan kesalahan pseudo construction yaitu berupa pseudo benar pada soal $d$ serta mengalami kesalahan misconstruction untuk soal $a$ dan soal $c$. Untuk soal nomor $a$, awalnya subjek M1 mengira bahwa $\emptyset$ dan $\{\varnothing\}$ merupakan himpunan yang sama. Oleh karena itu, M1 mengartikan bahwa himpunan tersebut tidak mempunyai elemen. Berikut kutipan wawancara peneliti dengan subjek M1 terkait dengan jawaban soal $a$.

P : Mengapa Anda menjawab soal ini (sambil menunjuk soal a) dengan jawaban "benar"? Mohon dijelaskan.

$M 1$ : insting saja pak.

$P \quad$ : dapat dijelaskan mengapa?

M1 : sebetulnya ini kan himpunan dari himpunan kosong, jadi ini merupakan himpunan kosong. Di dalam bimpunan $\{\varnothing\}$ terdapat himpunan kosong, karena bimpunan kosong tidak mempunyai anggota, berarti $\{\varnothing\}$ kosong dan tidak ada anggotanya

Untuk menggali informasi mengenai pengetahuan subjek M1 tentang pengertian himpunan kosong dan penulisan himpunan maka peneliti memberi beberapa pertanyaan dalam kutipan berikut.

$P \quad$ : Jadi begitu alasannya. Lantas menurut Anda bimpunan itu apa?

M1 : himpunan itu adalah sekelompok dari anggota-anggota yang berdiri sendiri tapi ada batasannya.

$P \quad$ : maksudnya batasan itu apa?

M1 : ada rumusnya pak.

$P \quad$ : Nah sekarang, kalau saya mempunyai himpunan yang isinya 1, 2, 3, 4 bagaimana cara menuliskannya?

M1 : (menulis $\{1,2,3,4\})$

$P \quad:$ Kalau urutannya diubah bagaimana, misal $\{2,1,3,4\}$ apakah boleh?

M1 : tidak apa-apa pak.

$P$ : Jike anggotanya 2, 2, 3, 1, 1, 3, 4, 4, 4 bagaimana cara Anda menuliskan notasi bimpunannya?

M1 : (diam tidak menjawab, dan berpikir lama)

$P \quad$ : Kalau saya menuliskannya seperti ini $(\{1,1,2,2,3,3,4,4,4\})$ bagaimana?

M1 : boleh pak.

$P \quad$ : Kalau saya menulis seperti ini $(\{1,2,3,4\})$ bagaimana? 


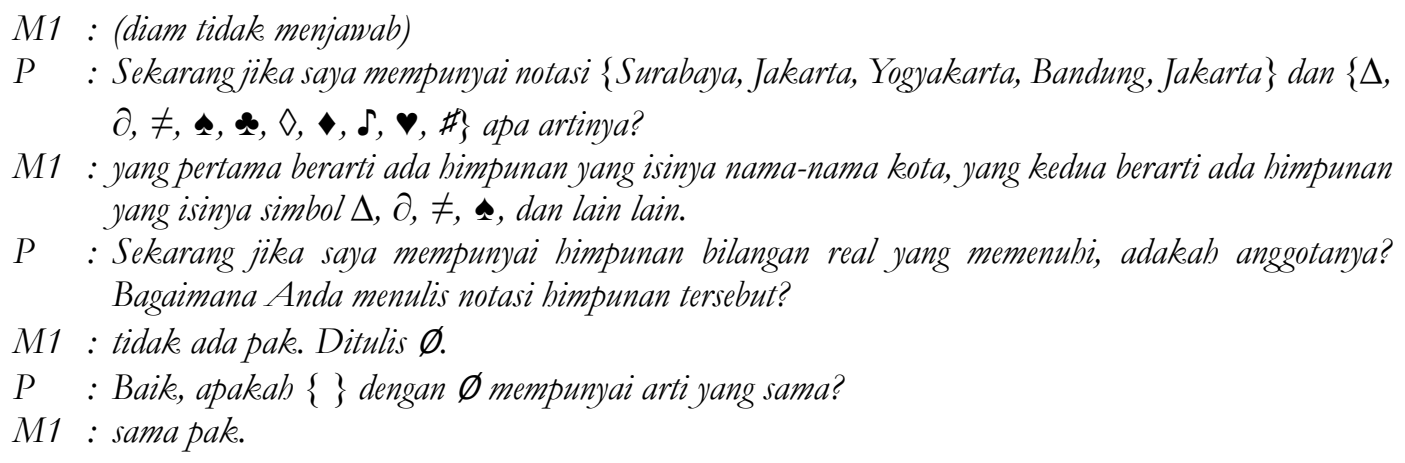

Dari kutipan tersebut terlihat bahwa M1 belum benar dalam memberikan pengertian tentang himpunan serta belum bisa memaknai anggota dari suatu himpunan dan cara penulisannya. Dapat diketahui pula bahwa M1 belum menguasai konsep himpunan kosong. Sebenarnya ia telah paham mengenai arti dari himpunan kosong tetapi belum bisa membedakan antara himpunan kosong dengan himpunan tidak kosong yang beranggotakan himpunan kosong. Oleh karena itu subjek M1 mengalami misconstruction pada saat mengerjakan soal $a$. Untuk membantu M1 dalam mengatasi kesalahan tersebut, peneliti berusaha untuk memberikan scaffolding (intervensi dengan memberikan bantuan secukupnya) sebagai berikut.

$P \quad:$ Dengan mengaitkan notasi $\{\Delta, \partial, \neq, \boldsymbol{\varphi}, \boldsymbol{\mathbf { s }}, \diamond, \diamond, \boldsymbol{\delta}, \boldsymbol{\bullet}, \#, \#\},\{\}$, dan $\{\varnothing\}$, apakah \{\} dengan $\{\varnothing\}$ mempunyai arti yang sama? Jelaskan.

M1 : (berpikir agak lama) tidak pak, \{\} dengan $\{\varnothing\}$ tidak sama. \{\} berarti bimpunan kosong dan $\{\varnothing\}$ adalah himpunan himpunan kosong.

$P \quad$ : bagaimana keanggotaannya?

$M 1$ : untuk \{\} tidak mempunyai anggota, dan $\{\varnothing\}$ anggotanya adalab himpunan kosong.

$P \quad$ : baik, jadi apakah sekarang Anda sudah paham?

M1 : sudah pak.

Untuk soal nomor $c$, subjek M1 juga mengalami kesalahan berupa misconstruction. Ia belum bisa membedakan dengan jelas makna dari elemen dan subset dari suatu himpunan. Hal ini terlihat dari kutipan berikut ini.

$P \quad:$ Untuk soal nomor c mengapa Anda menjawab seperti ini? (menunjukkan jawaban yang ditulis oleh mahasiswa).

M1 : Karena $\wp(A)$ mempunyai elemen yang isinya himpunan dari anggota $A$.

$P \quad$ : Jika saya mempunyai $A=\{1,2,3\}$, berarti himpunan dari anggota $A$ adalah $\{1,2,3\}$ begitu maksudnya?

M1 : iya pak, tapi ada lagi pak, $\{1,2\},\{2,3\},\{1,3\},\{1\},\{2\},\{3\}$.

$P \quad$ : maksud saudara subset dari $A$ ? benar demikian?

M1 : iya pak, maksud saya subset dari $\boldsymbol{A}$.

$P \quad$ : lantas mengapa Anda menuliskan power set merupakan bimpunan dari anggota $A$ ?

M1 : saya mengiranya demikian pak.

Dari dialog tersebut terlihat bahwa M1 belum memahami arti power set, elemen dan subset dari suatu himpunan $A$. Utamanya pada saat menyebutkan elemen dari power set suatu 
himpunan. Lebih lanjut peneliti melakukan tanya jawab sebagai berikut.

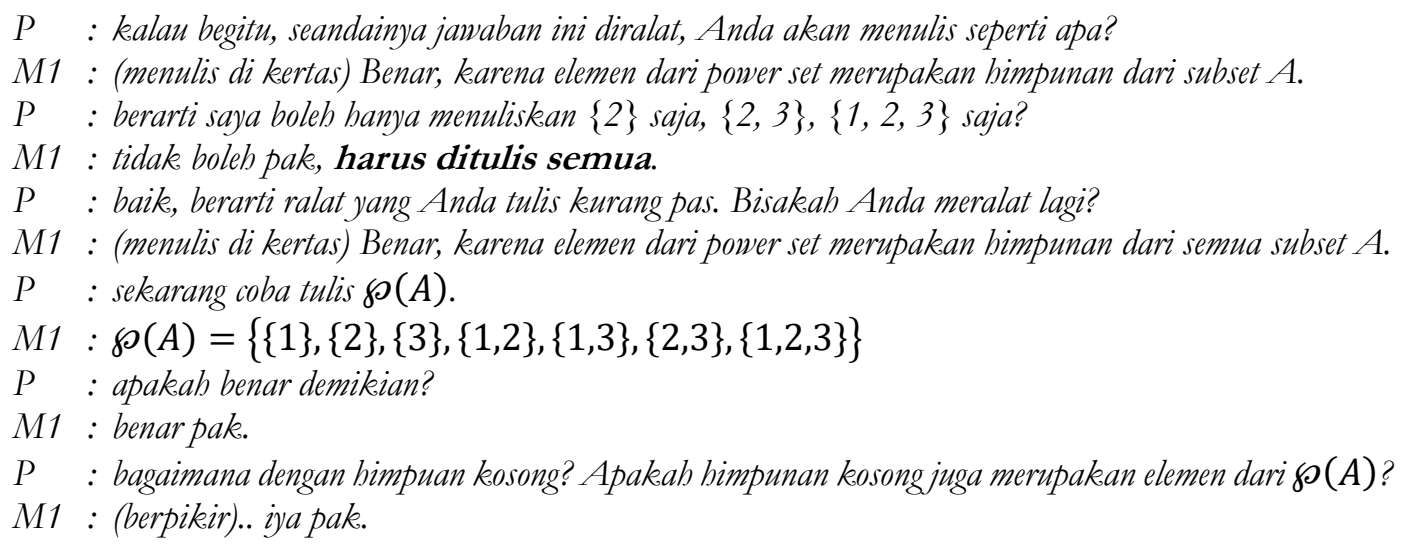

Sebenarnya M1 telah mengetahui bahwa power set $A$ adalah himpunan dari semua subset $A$ akan tetapi masih keliru menyebutkannya pada saat ditanyai pertama kali. Setelah diberi pertanyaan-pertanyaan lebih lanjut oleh peneliti ternyata M1 bisa membenarkan pernyataan awalnya yang masih salah tersebut. Untuk mengetahui lebih lanjut mengenai pengetahuan M1 tentang perbedaan elemen dari power set $A$ dan elemen dari $A$, maka peneliti melakukan dialog sebagai berikut.

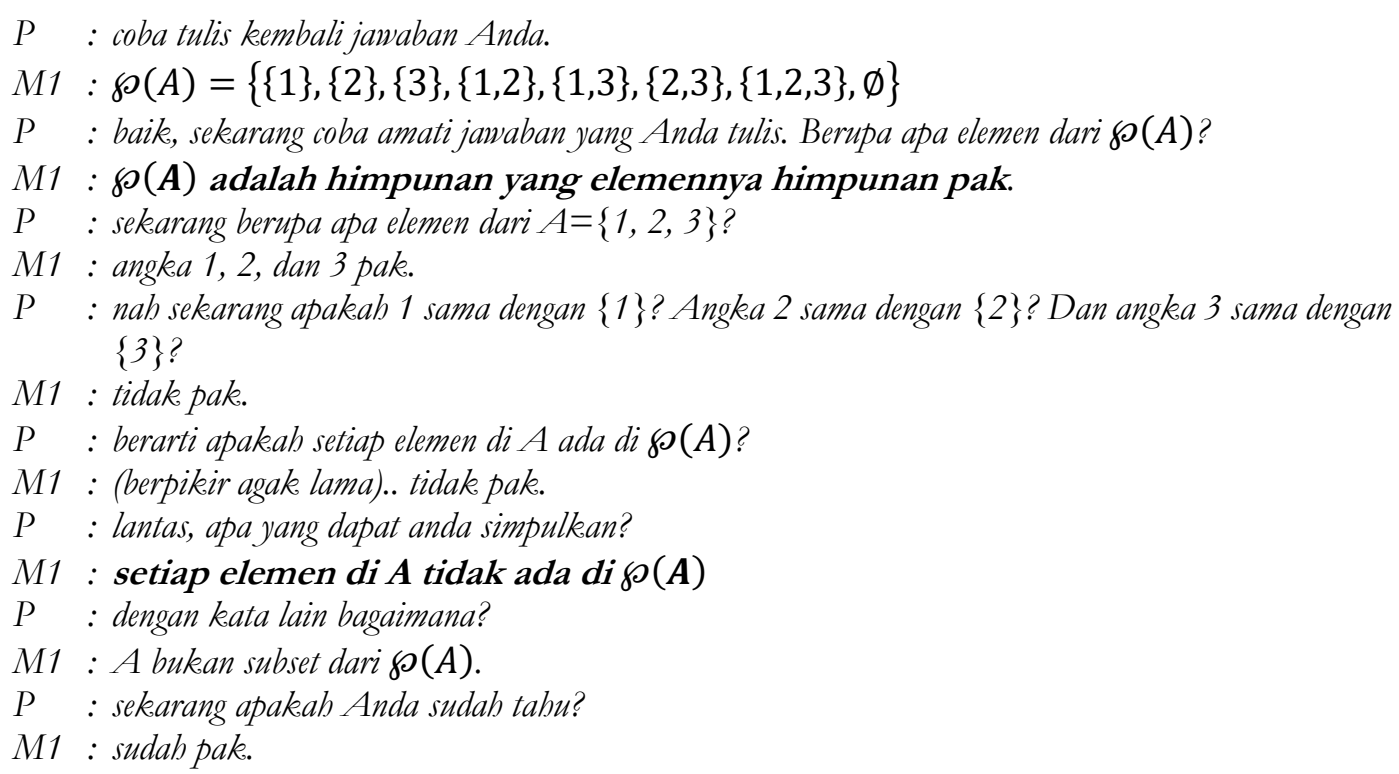

Berdasarkan dialog tersebut terlihat bahwa awalnya M1 belum bisa membedakan antara 1 dan $\{1\}$, ia mengira bahwa keduanya sama. Namun, setelah diberi cognitiveconflict maka M1 bisa membedakan antara keduanya yaitu elemen dari power set $A$ dan elemen dari himpunan A. Lebih lanjut ia juga bisa memahami bahwa jawabannya untuk nomor tersebut salah dan bisa menyatakan pernyataan yang benar.

Untuk soal $d$, subjek M1 menjawab Benar namun dengan alasan yang kurang tepat. Hal ini menunjukkan bahwa ia melakukan kesalahan berbentuk pseudo benar. Seperti pada saat 
mengerjakan soal $c$, dari alasan yang diberikannya terlihat bahwa M1 masih belum bisa membedakan elemen power set himpunan $A$ dengan elemen himpunan $A$. Utamanya masih belum bisa membedakan $\{a\}$ dan $a$ untuk sebarang bilangan real $a$. Demikian juga setelah diberi soal tes pendukung, ia masih kebingungan mengenai alasan dari jawabannya. Subjek M1 juga belum mengetahui perbedaan antara himpunan $A$ dengan $\{A\}$. Gambar 3 merupakan jawaban subjek M1 pada soal tes pendukung.

\begin{tabular}{|c|c|c|c|c|}
\hline Pernyataan & Alternatif dan Alasan & Setuju & $\begin{array}{l}\text { Tidak } \\
\text { Setuju }\end{array}$ & $\begin{array}{l}\text { Tidak } \\
\text { Tahu }\end{array}$ \\
\hline \multirow[t]{2}{*}{$\begin{array}{l}\{\emptyset] \text { tidak mempunyai } \\
\text { elemen. }\end{array}$} & $\begin{array}{l}\text { Benar. } \\
\text { Karena himpunan tersebut } \\
\text { merupakan himpunan } \\
\text { kosong yang berarti } \\
\text { himpunan yang tidak } \\
\text { memiliki elemen } \\
\text { (anggota). }\end{array}$ & & $\checkmark$ & \\
\hline & $\begin{array}{l}\text { Salah. } \\
\text { Himpunan tersebut } \\
\text { mempunyai } 1 \text { elemen } \\
\text { (anggota) yaitu } \emptyset \text {. }\end{array}$ & $\checkmark$ & & \\
\hline \multirow{3}{*}{$\emptyset \in \wp(A)$} & $\begin{array}{l}\text { Benar. } \\
\text { Karena } \emptyset \text { merupakan } \\
\text { subset dari sebarang } \\
\text { himpunan } A \text {. Jadi } \emptyset \\
\text { merupakan anggota dari } \\
\text { power set dari himpunan } A \\
(\wp(A)) \text {. }\end{array}$ & $\checkmark$ & & \\
\hline & $\begin{array}{l}\text { Benar. } \\
\text { Karena himpunan kosong } \\
\text { sudah pasti merupakan } \\
\text { subset dari } \wp(A) \text {. }\end{array}$ & $\checkmark$ & & \\
\hline & $\begin{array}{l}\text { Salah } \\
\text { Karena himpunan } A \text { pasti } \\
\text { punya anggota jadi } \\
\text { seharusnya } \\
\emptyset \notin \wp(A) \text {. }\end{array}$ & & $\checkmark$ & \\
\hline
\end{tabular}

(a)

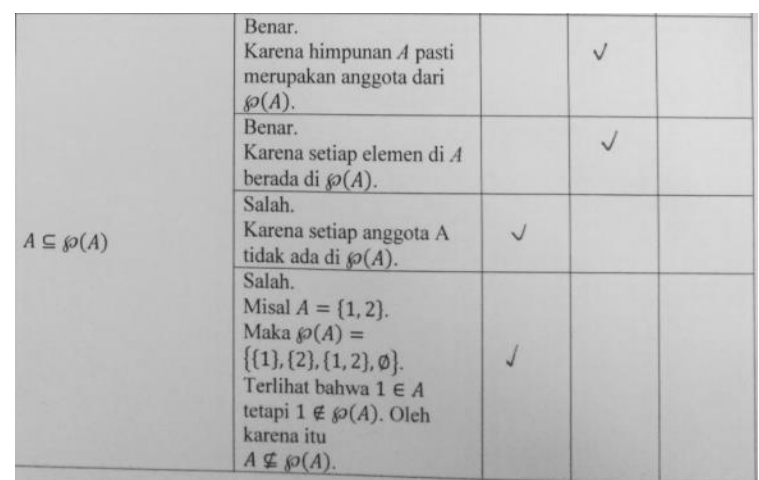

(b)

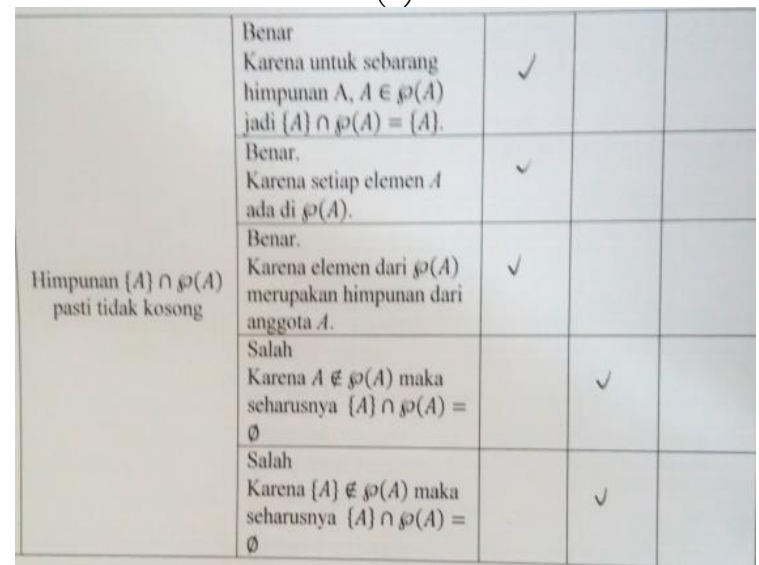

(c)

Gambar 3. Hasil Jawaban M1 pada soal tes pendukung

\section{B. Subjek M2}

Adapun hasil jawaban M2 pada soal tes utama diperoleh hasil pada Gambar 4 berikut ini.

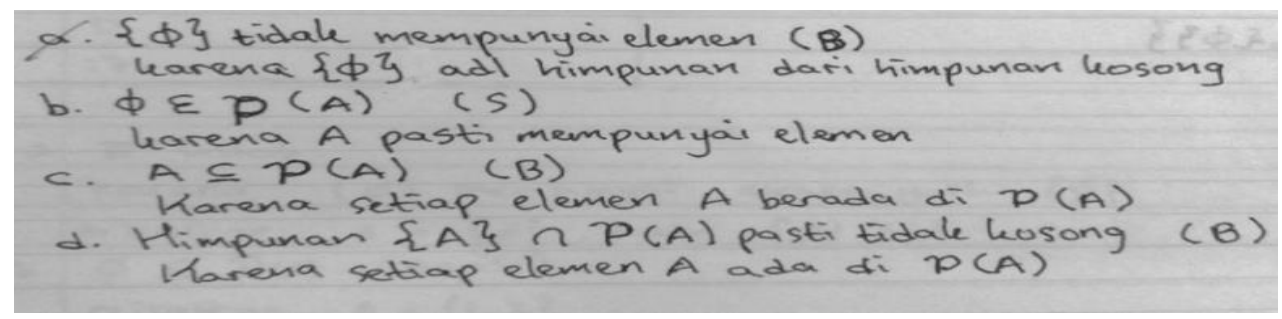

Gambar 4. Hasil Jawaban M2 pada soal tes utama

Pada soal $a$, subjek M2 telah mengetahui bahwa himpunan tersebut merupakan 
himpunan dari himpunan kosong. Akan tetapi ia belum memahami maknanya, dan mengira bahwa himpunan tersebut sama dengan himpunan kosong $(\varnothing)$. Jawaban dari subjek M2 sama dengan M1 pada saat ditanyai mengenai alasannya menjawab benar untuk soal tersebut. Keduanya mengira bahwa \{\} dan $\{\varnothing\}$ merupakan himpunan yang sama yaitu himpunan yang tidak mempunyai elemen (anggota). Oleh karena itu subjek M2 juga dikategorikan mengalami lubang konstruksi seperti M1 untuk soal $a$. Dengan bentuk defragmentasi yang sama dengan M1, yaitu dengan memberikan scaffolding berupa bantuan secukupnya seperti kutipan dialog berikut, ternyata M2 telah menyadari kesalahannya.

$P \quad:$ Sekarang jika saya mempunyai notasi $\{$ Surabaya, Jakarta, Yogyakarta, Bandung, Jakarta\} dan $\{\Delta$, $\partial, \neq, \boldsymbol{\uparrow}, \boldsymbol{\infty}, \diamond, \bullet, \boldsymbol{\delta}, \boldsymbol{\varphi}, \#, \#$ apa artinya?

M2 : notasi \{Surabaya, Jakarta, Yogyakarta, Bandung, Jakarta\} berarti bimpunan dari nama kota yang isinya Surabaya, Jakarta, Yogyakarta, Bandung, dan Jakarta. Notasi $\{\Delta, \partial, \neq, \boldsymbol{\bullet}, \diamond, \downarrow, \mathcal{\delta}, \mathbf{\varphi}$, \#, \#\} berarti bimpunan dari simbol-simbol yang isinya $\Delta, \partial, \neq, \boldsymbol{\bullet}, \boldsymbol{\infty}, \diamond, \bullet, \boldsymbol{\delta}, \boldsymbol{\varphi}, \#$

$P \quad:$ Sekarang jika saya mempunyai bimpunan bilangan real yang memenubi $x^{2}=-4$, adakah anggotanya? Bagaimana Anda menulis notasi bimpunan tersebut?

M2 : tidak ada pak. Ditulis \{\}

$P \quad:$ Baik, apakah \{\} dengan $\emptyset$ mempunyai arti yang sama?

M2 : sama pak

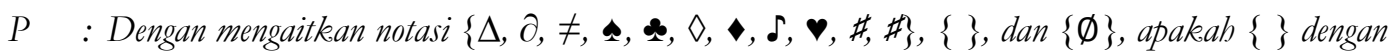
$\{\varnothing\}$ mempunyai arti yang sama? Jelaskan.

M2 : beda pak kalau \{ \} artinya bimpunan yang tidak mempunyai elemen dan disebut bimpunan kosong. Sedangkan $\{\varnothing\}$ artinya himpunan yang elemennya simbol himpunan kosong.

$P \quad:$ baik, jadi apakah sekarang Anda sudah paham?

M2 : iyapak.

Pada soal b, subjek M2 menjawab salah dengan menyebutkan alasan bahwa setiap himpunan A pasti mempunyai elemen. Hal inilah yang merupakan kesalahan utama M1 pada saat mengonstruksi konsep sebarang himpunan A. Menurutnya jika himpunan diberi simbol dengan huruf besar, maka pasti himpunan tersebut merupakan himpunan yang mempunyai elemen. Ia tidak mempertimbangkan kemungkinan bahwa himpunan tersebut merupakan himpunan kosong. Berikut kutipan wawancara peneliti terkait dengan jawaban M2 pada soal b.

$P \quad:$ Untuk soal nomor 1.b mengapa Anda menjawab seperti ini? (menunjukkan jawaban yang ditulis oleh mahasiswa).

M2 : ya karena A pasti mempunyai elemen pak?

$P \quad:$ Apa benar? Bagaimana jika A merupakan bimpunan kosong? Apakab boleh?

M2 : (diam berpikir sejenak).. Boleh pak, A boleh merupakan bimpunan kosong.

$P \quad$ : Baik, jika A merupakan himpunan kosong apakah A mempunyai elemen?

M2 : tidak pak.

$P \quad:$ berarti apakah A pasti mempunyai elemen?

M2 : tidak pak. A bisa mempunyai elemen dan A juga bisa tidak mempunyai elemen.

$P \quad$ : baik, berarti Anda tabu mengapa alasan dari jawaban yang Anda tulis salah?

M2 : sekarang saya tabu pak. 
Berdasarkan dialog tersebut, peneliti langsung memberikan petunjuk bahwa himpunan $A$ mungkin saja merupakan himpunan kosong. Subjek M2 kemudian menyadari hal ini dan memahami kenapa alasannya untuk soal $b$ tidak logis. Oleh karena itu dapat disimpulkan bahwa M2 mengalami kesalahan berpikir logis. Untuk mengatasi hal tersebut, peneliti mencoba untuk melakukan defragmentasi dengan pemunculan skema mengenai keanggotaan power set dari suatu himpunan. Berikut scaffolding yang diberikan peneliti untuk memunculkan skema tersebut.

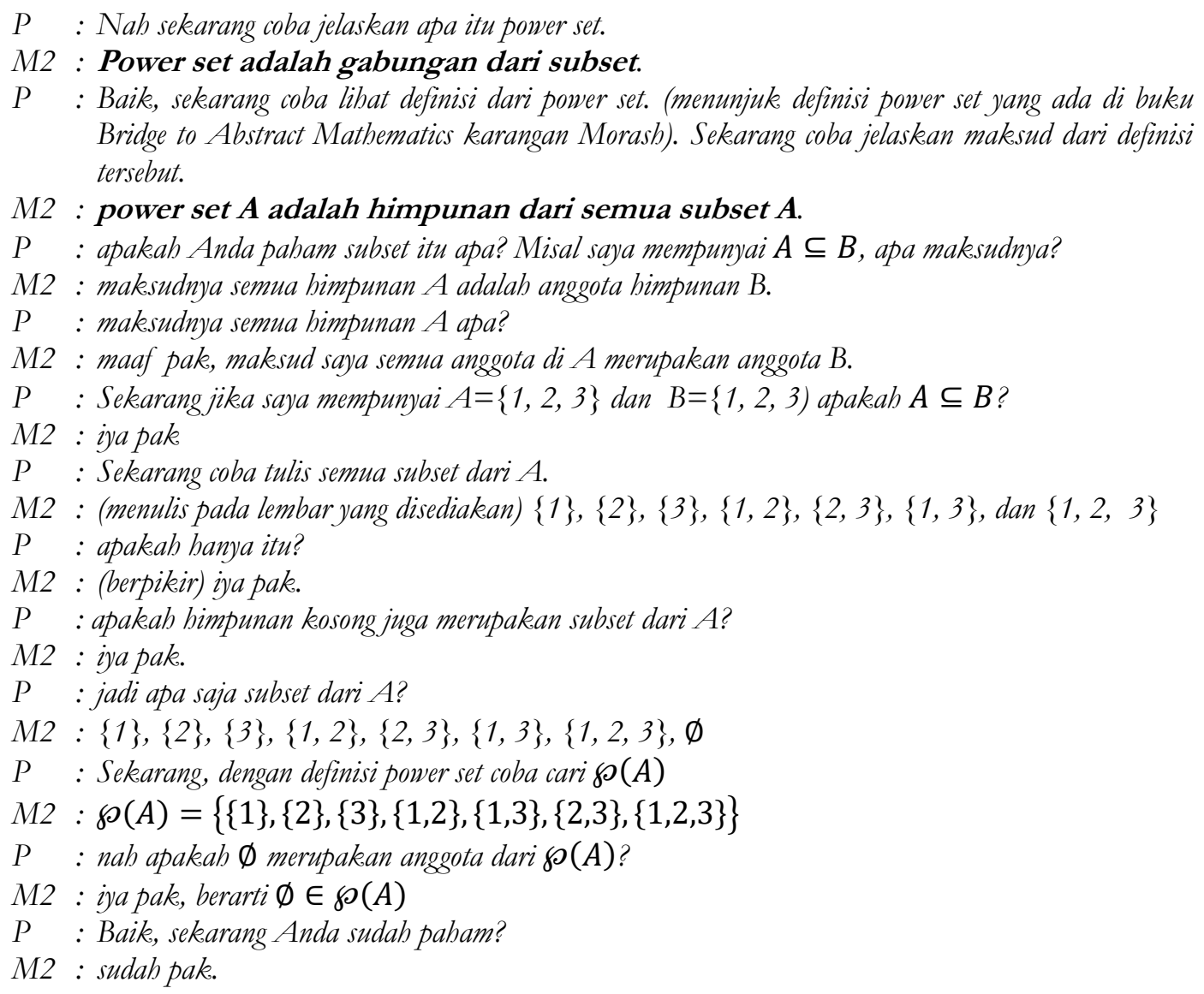
Bridge to Abstract Mathematics karangan Morash). Sekarang coba jelaskan maksud dari definisi tersebut.

M2 : power set $A$ adalah himpunan dari semua subset $A$.

$P \quad$ : apakah Anda paham subset itu apa? Misal saya mempunyai $A \subseteq B$, apa maksudnya?

$M 2$ : maksudnya semua bimpunan $A$ adalab anggota bimpunan $B$.

$P \quad:$ maksudnya semua bimpunan $A$ apa?

M2 : maaf pak, maksud saya semua anggota di $A$ merupakan anggota $B$.

$P \quad$ : Sekarang jika saya mempunyai $A=\{1,2,3\}$ dan $B=\{1,2,3)$ apakah $A \subseteq B$ ?

M2 : iya pak

$P \quad:$ Sekarang coba tulis semua subset dari $A$.

M2 : (menulis pada lembar yang disediakan) $\{1\},\{2\},\{3\},\{1,2\},\{2,3\},\{1,3\}$, dan $\{1,2,3\}$

$P \quad:$ apakah banya itu?

M2 : (berpikir) iya pak.

$P \quad$ : apakah bimpunan kosong juga merupakan subset dari $A$ ?

M2 : iyapak.

$P \quad$ : jadi apa saja subset dari $A$ ?

$M 2:\{1\},\{2\},\{3\},\{1,2\},\{2,3\},\{1,3\},\{1,2,3\}, \varnothing$

$P \quad:$ Sekarang, dengan definisi power set coba cari $\wp(A)$

$M 2: \wp(A)=\{\{1\},\{2\},\{3\},\{1,2\},\{1,3\},\{2,3\},\{1,2,3\}\}$

$P \quad:$ nah apakah $\emptyset$ merupakan anggota dari $\wp(A)$ ?

M2 : iya pak, berarti $\varnothing \in \wp(A)$

$P \quad$ : Baik, sekarang Anda sudah paham?

M2 : sudahpak.

Seperti halnya M1, M2 juga awalnya tidak menuliskan $\emptyset$ sebagai subset dari sebarang himpunan $A$. Namun setelah diingatkan oleh peneliti, ia kemudian menyadarinya dan dapat mengetahui kesalahan jawabannya untuk soal $b$.

Pada soal $c$, subjek M2 memberikan alasan yang mirip dengan M1. Ia belum bisa membedakan dengan jelas makna dari elemen dan subset dari suatu himpunan. Utamanya tidak bisa membedakan antara bilangan real $a$ dan $\{a\}$. Sehingga bisa dikategorikan bahwa M2 melakukan kesalahanmisconstruction pada saat menyelesaikan soal c. Namun, dengan pemberian cognitive conflict yang sama seperti pada subjek M1, akhirnya ia bisa membedakan keduanya. 
Untuk soal $d$, jawaban M2 sudah benar dengan menjawab Benar, akan tetapi dengan alasan yang masih kurang tepat. Ia memberikan alasan yang sama dengan soal $c$ yaitu karena setiap elemen di $A$ berada di $\wp(A)$. Hal ini menunjukkan bahwa M2 belum bisa membedakan simbol dan makna dari elemen dan subset dari suatu himpunan. Oleh karena itu bisa dikatakan bahwa M2 melakukan kesalahan pseudo benar, yakni memperoleh jawaban benar namun sebenarnya penalarannya salah.Gambar 5 merupakan hasil jawaban subjek M2 pada soal tes pendukung.
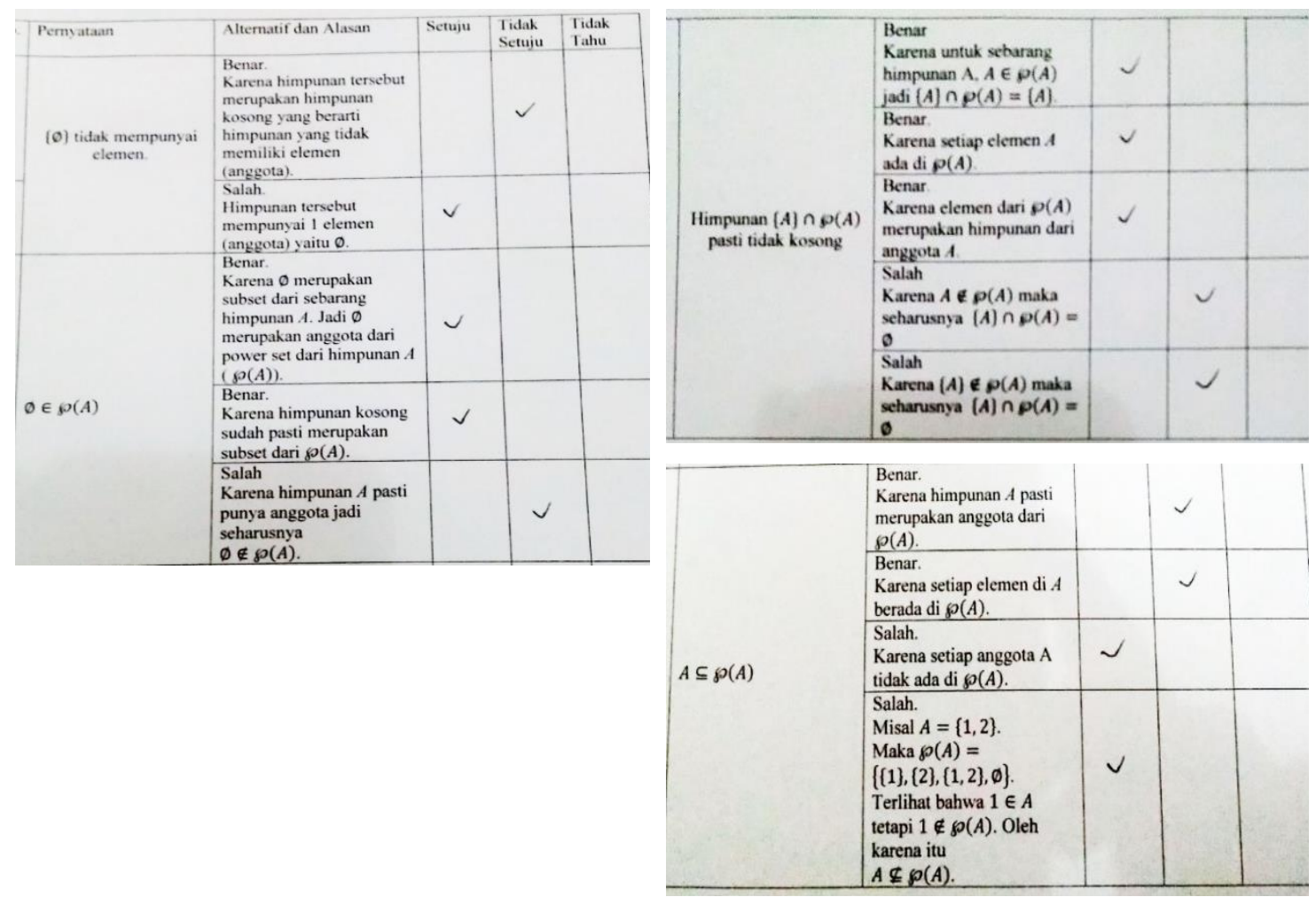

Gambar 5. Hasil Jawaban M2 pada soal tes pendukung

\section{Subjek M3}

Adapun hasil jawaban M3 pada soal tes utama dan hasil wawancara terhadap subjek M3 diperoleh hasil pada Gambar 6 berikut ini.

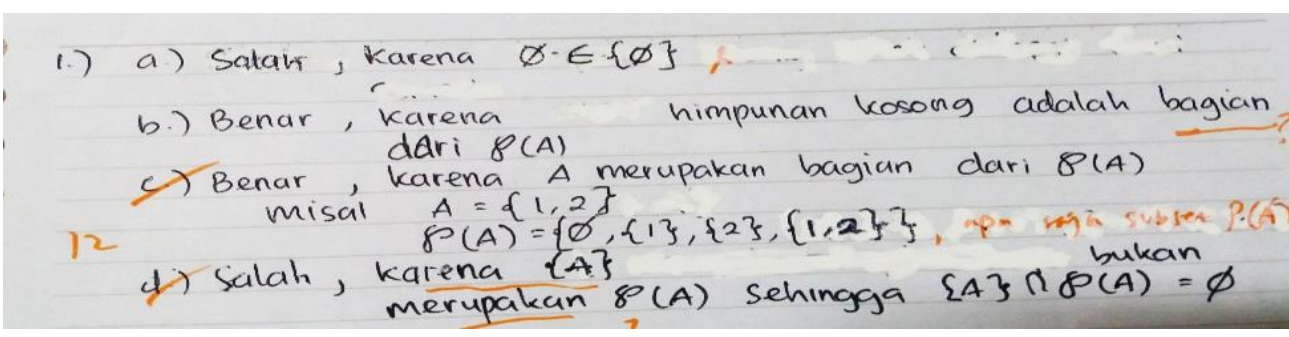

Gambar 6. Hasil Jawaban M3 pada soal tes utama 
Pada soal $c$, subjek M3 menjawab Benar dengan memberikan contoh himpunan $\boldsymbol{A}=$ $\{\mathbf{1 , 2}\}$ dan menyebutkan power set dari himpunan tersebut. Dari hasil jawaban dan wawancara oleh peneliti dapat diketahui bahwa M3 sudah paham mengenai arti dari power set dan bisa menyebutkan keanggotaannya. Ia juga paham mengenai arti dari subset dan elemen dari suatu himpunan $A$, akan tetapi tidak bisa mengoneksikan dan membedakan keduanya. Sama dengan subjek M1 dan M2, subjek M3 juga belum bisa membedakan antara $\{a\}$ dan $a$, untuk sebarang bilangan real $a$. Oleh karena itu, kesalahan yang dilakukan M3 pada soal ini ditegorikan ke dalam misconnection. Berikut kutipan wawancara subjek M3 pada soal $c$.

$P \quad:$ Untuk soal nomor 1.c mengapa Anda menjawab seperti ini? (menunjukkan jawaban yang ditulis oleh mahasiswa).

M3 : Karena $A=\{1,2\}$ ada di $\wp(\boldsymbol{A})$.

$P \quad$ : sekarang coba sebutkan definisi dari $\boldsymbol{A} \subseteq \boldsymbol{B}$ ?

M3 : setiap anggota $A$ ada di $B$.

$P \quad$ : baik, sekarang coba sebutkan anggota dari $\wp(\boldsymbol{A})$ ?

$M 3: \emptyset,\{\mathbf{1}\},\{\mathbf{2}\},\{\mathbf{1}, \mathbf{2}\}$

$P \quad:$ sekarang sebutkan angoota dari $A$.

M3 : 1 dan 2.

$P \quad$ : nah, apakah 1 sama dengan $\{1\}$ ? Apakah 2 sama dengan $\{2\}$ ?

M3 : tidakpak.

$P \quad:$ berarti apakah 1 merupakan anggota $\wp(\boldsymbol{A})$ ?

M3 : tidak pak.

$P \quad$ : apa yang dapat Anda simpulkan?

M3 : anggota $A$ tidak ada di $\wp(\boldsymbol{A})$.

$P \quad:$ berarti pernyataan $\boldsymbol{A} \subseteq \wp(\boldsymbol{A})$ bagaimana

M3 : salah pak.

$P \quad$ : sekarang apakah Anda sudah tabu?

M3 : iyapak.

Dari kutipan wawancara tersebut, terlihat bahwa dengan memberikan cognitive conflict yaitu menanyakan perbedaan antara 1 dan $\{1\}$, maka akhirnya subjek M3 mengetahui kesalahannya.

Pada soal $d$, M3 menjawab Salah dengan alasan bahwa $\{\boldsymbol{A}\} \cap \wp(\boldsymbol{A})=\emptyset$. Subjek M3 melakukan kesalahan pada saat menjawab soal tersebut, namun setelah dilakukan wawancara ternyata ia paham bahwa jawabannya salah dan bisa memberikan jawaban yang benar yaitu $\{\boldsymbol{A}\} \cap \wp(\boldsymbol{A})=\boldsymbol{A}$. Oleh karena itu kesalahan yang dilakukan oleh M3 pada saat mengerjakan soal $d$ dapat dikategorikan ke dalam konstruksi pseudo salah. Berikut kutipan wawancara peneliti dengan subjek M3 untuk soal $d$.

$P \quad:$ Untuk soal nomor 1.d mengapa Anda menjawab seperti ini? (menunjukean jawaban yang ditulis oleh mahasiswa).

M3 : maaf pak saya salah, karena $\{A\}$ pasti anggota $\wp(\boldsymbol{A})$,

seharusnya $\{\boldsymbol{A}\} \cap \wp(\boldsymbol{A})=\boldsymbol{A}$..

Jadi $\{\boldsymbol{A}\} \cap \wp(\boldsymbol{A})$ pasti tidak kosong. 
$P \quad$ :baik berarti Anda sudah paham.

M3 :iya pak.

Untuk soal ini, tampaknya defragmentasi alami telah terjadi pada subjek M3. Ia sudah menyadari kesalahan yang dilakukannya dan bahkan bisa memberikan pernyataan yang benar untuk soal tersebut.

Berikut ini merupakan hasil jawaban M3 pada soal tes pendukung.
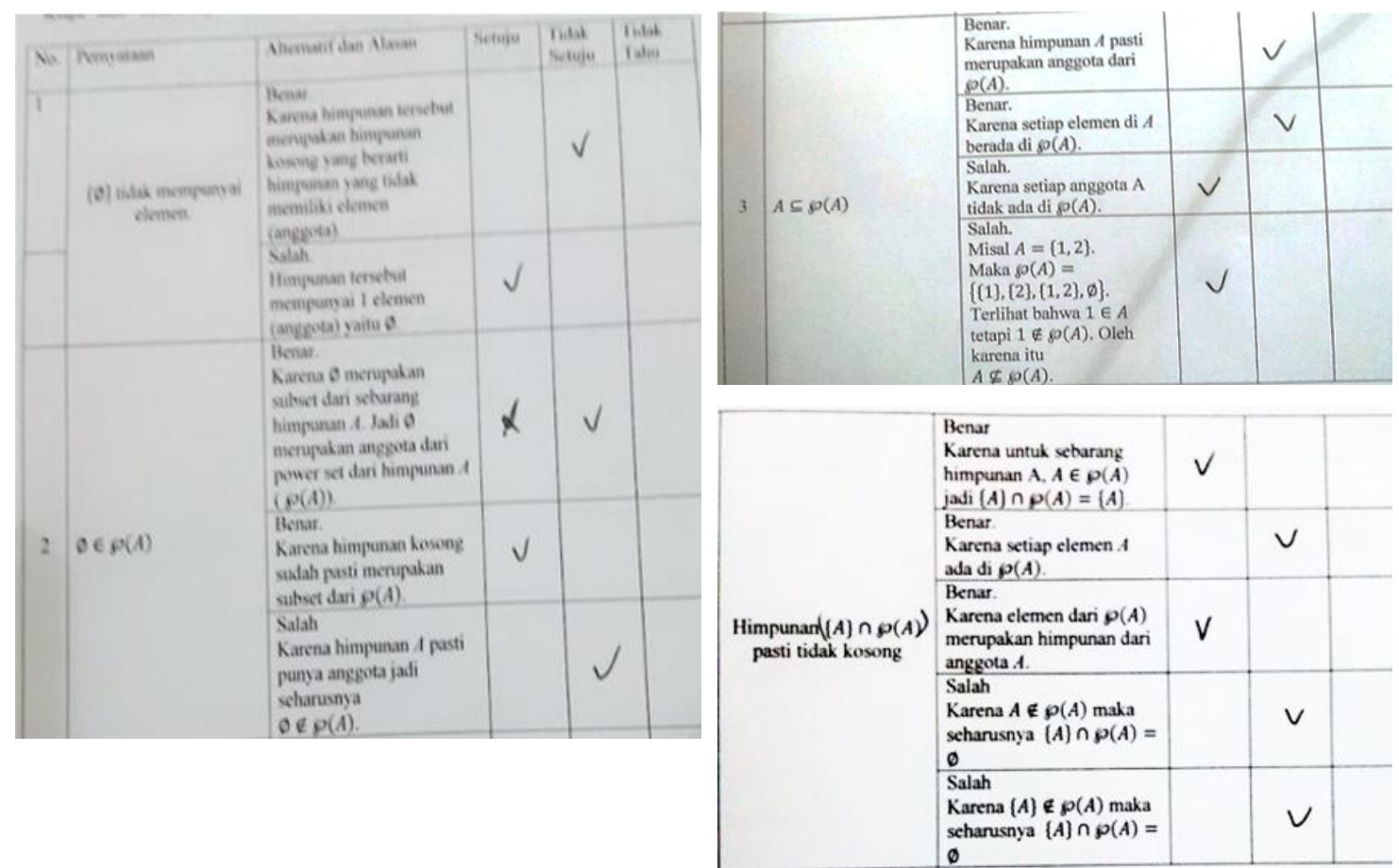

Gambar 7. Hasil Jawaban M3 pada soal tes pendukung

\section{Pembahasan}

Dari hasil penelitian yang telah dipaparkan, meskipun materi himpunan merupakan materi yang sudah diperoleh mahasiswa pada saat mereka menempuh bangku sekolah menengah, ternyata masih ditemukan kesalahan konsep yang dilakukan oleh mahasiswa. Kesalahan banyak dilakukan oleh mahasiswa dari kategori kemampuan kognitif rendah. Hal ini sesuai dengan pendapat Tall dan Razali (1993) yang menyatakan bahwa siswa dengan kemampuan rendah sangat sering mengalami kesulitan dalam mengambil informasi yang telah diperoleh.

Dalam menyelesaikan soal tes utama yang diberikan peneliti, ketiga subjek mengalami pseudo konstruksi, baik dalam bentuk pseudo benar atau pseudo salah. Pseudo benar dilakukan oleh M1 dan M2 ketika menjawab soal $d$, mereka menjawab Benar tetapi setelah ditelusuri ternyata alasan mereka kurang tepat. Hasil ini selaras dengan Subanji (2015), bahwa seolah-olah jawaban siswa benar, namun setelah ditelusuri lebih mendalam, ternyata apa yang 
dipikir oleh siswa tidak sesuai dengan substantif konsepnya. Sedangkan pseudo salah dilakukan oleh M3 ketika menjawab soal tersebut. Ia menjawab Salah, namun setelah dilakukan wawancara ia dapat membenarkan jawabannya. Untuk mengatasi pseudo konstruksi yang dilakukan mahasiswa, peneliti melakukan defragmentasi berupa pemberian cognitive conflict dengan memunculkan skema dalam pikiran mahasiswa tentang perbedaan antara elemen dan subset serta perbedaan antara bilangan real $a$ dan $\{a\}$. Bentuk defragmentasi yang sama juga dilakukan oleh Wibawa dkk (2018a) dalam memperbaiki kesalahan yang dilakukan mahasiswa pada saat memecahkan masalah matematis.

Misconstruction merupakan proses pembentukan konsep matematika tidak sempurna, dalam pembentukan konsep, ada bagian dari konsep yang tidak terkonstruksi (Subanji, 2015). Hal ini terjadi ketika subjek membangun konsep tentang himpunan kosong $(\varnothing)$, elemen suatu himpunan, subset dan power set. Untuk memperbaiki kesalahan tersebut, peneliti memberikan scaffolding dengan meminta subjek untuk menyebutkan pengertian masing-masing istilahistilah tersebut dan mengarahkan subjek untuk memahami keanggotaan (elemen) dari suatu himpunan. Untuk menata kembali konsep power set sebarang himpunan $A$ dan keanggotaannya, dilakukan pemberian cognitive conflict berupa pemunculan skema berpikir mengenai perbedaan antara elemen dan subset. Defragmentasi ini sesuai dengan hal yang dilakukan Wibawa dkk (2018b) dalam mengatasi subjek penelitiannya yang mengalami Misconstruction.

Subjek M3 mengalami misconnection pada saat menjawab soal $c$. Ia sudah paham mengenai arti power set dan bisa menyebutkan keanggotaannya. Ia juga paham arti subset dan elemen dari suatu himpunan $A$, akan tetapi tidak bisa mengoneksikan dan membedakan keduanya. Hal ini merupakan proses pembentukan konsep matematika, dimana bagianbagian konsep telah terkonstruksi namun belum ada koneksi antar bagian konsep (Subanji, 2015).

Kesalahan berpikir logis dialami subjek M2 ketika menjawab soal $b$. Ia menganggap bahwa setiap himpunan pasti punya anggota. Untuk mengatasi hal tersebut, peneliti mencoba untuk melakukan defragmentasi dengan pemunculan skema mengenai keanggotaan power set dari suatu himpunan.

\section{SIMPULAN DAN SARAN}

Berdasarkan hasil dan pembahasan, diperoleh beberapa kesalahan mahasiswa pada saat mengonstruksi konsep matematika pada materi himpunan, yaitu: (1) Pseudo konstruksi, dalam 
bentuk pseudo benar dan pseudo salah, dimana mahasiswa belum bisa membedakan antara himpunan $A$ dan himpunan $\{\mathrm{A}\}$, serta tidak bisa membedakan antara bilangan real $a$ dan $\{a\}$. Oleh karena itu, mereka menganggap bahwa setiap elemen di himpunan $A$ juga berada di $\wp(A)$ sehingga irisan keduanya tidak kosong, (2) Misconstruction, mahasiswa belum memahami dengan benar arti dari elemen dan subset dari sebarang himpunan $A$. Konsep power set juga belum dipahami dengan baik oleh mahasiswa sehingga tidak bisa membedakan antara elemen dari himpunan $A$ dan elemen dari power set $A$, (3) Misconnection, dimana mahasiswa telah mengetahui dan memahami dengan baik arti subset sebarang himpunan $A$, power set himpunan $A$, dan elemen dari himpunan $A$. Akan tetapi ia belum bisa membuat koneksi antara konsep-konsep tersebut, dan (4) Kesalahan berpikir logis, mahasiswa beranggapan bahwa himpunan $A$ pasti mempunyai elemen dan tidak mempertimbangkan kemungkinan himpunan kosong. Alasan ini tidak logis untuk pernyataan yang ditanyakan yaitu “ $\emptyset \in \wp(A)$ ”. Mahasiswa juga masih belum benar dalam mengontruksi power set $A$ sehingga melakukan kesalahan ketika menjawab pertanyaan tersebut.

Bentuk defragmentasi atau proses menata kembali struktur berpikir mahasiswa yang mengalami kesalahan konstruksi konsep pada materi himpunan dilakukan melalui pemunculan skema dan perbaikan berpikir logis. Keduanya dilakukan melalui scaffolding dan cognitive conflict pada saat melakukan wawancara dengan subjek penelitian. Dalam menata kembali konsep himpunan kosong, dilakukan scaffolding berupa permintaan terhadap subjek untuk menyebutkan pengertiannya dan mengarahkan subjek untuk memahami keanggotaan (elemen) dari suatu himpunan. Untuk menata kembali konsep power set sebarang himpunan $A$ dan keanggotaannya, dilakukan pemberian cognitive conflictt berupa perbedaan antara elemen dan subset serta perbedaan antara bilangan real $a$ dan $\{a\}$.

Berdasarkan hasil penelitian, maka disarankan sebagai berikut: (1) Pada saat perkuliahan mengenai himpunan, dosen dapat memberikan penguatan konsep dengan memperlihatkan contoh-contoh kesalahan yang dilakukan mahasiswa berdasarkan penelitian ini. Sehingga para mahasiswa dapat mengetahui perbedaan konsep yang benar dan yang salah dan (2) Dosen hendaknya aktif untuk mengidentifikasi kesalahan konstruksi konsep mahasiswa pada materi lain untuk merancang pola pembelajaran yang lebih baik. 


\section{DAFTAR RUJUKAN}

Almeda, D., Cruz, E., \& Dy, A. (2013). Addressing Students' Misconceptions and Developing Their Conceptual Understanding and Procedural Skills on Fractions Using Manipulative Materials. Research Congress, De La Salle University Manila. Diakses pada tanggal 18 Juni 2017.

Ganal, N. N., \& Guiab, M. R. (2014). Problems and difficulties encountered by students towards mastering learning competencies in mathematics. Researchers World, 5, 25-37.

Subanji. (2015). Teori Kesalahan Konstruksi Konsep dan Pemecahan Masalab Matematika. Malang: UM Press.

Subanji. (2016). Teori Defragmentasi Struktur Berpikir dalam Mengkonstruksi Konsep dan Pemecahan Masalab Matematika. Malang: UM Press.

Tall, D., \& Razali, M. R. (1993). Diagnosing Student' Difficulties in Learning Mathematics. InternationalJournal of Mathematics Education Science, 24(2), 209-222. https://doi.org/10.1080/0020739930240206.

Wibawa, K. A., Nusantara, T., Subanji, \& Parta, I. N. (2018a). Defragmentasi Pengaktifan Skema Mahasiswa Untuk Memperbaiki Terjadinya Berpikir Pseudo Dalam Memecahkan Masalah Matematis. Prima: Jurnal Pendidikan Matematika, 2(2), 96 - 106.

Wibawa, K. A., Nusantara, T., Subanji, \& Parta, I. N. (2018b). Defragmentation of Student's Thinking Structuresin SolvingMathematical Problems based on CRA Framework. Proceeding 2nd International Conference on Statistics, Mathematics, Teaching, and Research. IOP Conf. Series: Journal of Physics: Conf. Series 1028 (2018) 012150, doi :10.1088/17426596/1028/1/012150. 